\title{
MOŻLIWOŚCI PROWADZENIA DZIAŁAŃ BOJOWYCH NA WODACH ŚRÓDLĄDOWYCH II RZECZYPOSPOLITEJ NA PRZYKŁADZIE FLOTYLLI RZECZNEJ MARYNARKI WOJENNEJ W PIŃSKU
}

\section{Wstęp}

iły Zbrojne II Rzeczypospolitej (RP) w swojej strukturze w latach 19181939 posiadały dwie jednostki wojskowe przeznaczone do prowadzenia działań bojowych na wodach śródlądowych. Były to Flotylle Rzeczne - Wiślana i Pińska. Pierwsza z nich swoją działalność rozpoczęła 23 grudnia 1918 r., a zakończyła z chwilą rozwiązania jesienią 1925 r. Druga jednostka - Flotylla Rzeczna Marynarki Wojennej (MW) w Pińsku funkcjonowała od 19 kwietnia 1919 r. do 29 września 1939 r. Jednak prowadzenie działań bojowych przez jednostki pływające każdej z nich było w znacznym stopniu uzależnione od co najmniej kilku czynników o charakterze: politycznym, geograficznym, organizacyjnym i technicznym. Poniżej zaprezentowano ograniczenia w ich działalności wynikające z: doktryny wojennej II RP, specyfiki wodnej Polesia, ocen dowódców i przełożonych, uwarunkowań związanych z parametrami technicznymi jednostek pływających ${ }^{1}$.

${ }^{1}$ I. Bieniecki, Poglady na zastosowanie Flotylli Pińskiej Marynarki Wojennej w działaniach bojowych i ich uwarunkowania (1919-1939), „Biuletyn Historyczny Muzeum Marynarki Wojennej w Gdyni” 1992, nr 12, s. 25-28; IDEM, Flotylla Rzeczna Polskiej Marynarki Wojennej w Pińsku w latach 1925-1935 w świetle sprawozdań inspektorów armii i oficerów Korpusu Kontrolerów, Toruń 1995, s. 1-302. Vide: J. Dyskant, Flotylla Rzeczna Marynarki Wojennej 1919-1939, Warszawa 1994, s. 1-389; IDEM, Wrzesień Flotylli Rzecznej, Warszawa 1988, s. 1-127. 


\section{Doktryna wojenna II RP a flotylle rzeczne}

Możliwości wykorzystania flotylli rzecznych na Polesiu w latach 1921-1939 były uwarunkowane m.in. ówczesną polską doktryną wojenną. Przy jej opracowaniu nawiązano do doświadczeń uzyskanych w czasie niedawnej wojny z Rosją bolszewicką, a także ustaleń polsko-francuskiej konwencji wojskowej z 21 lutego $1921 \mathrm{r}$. Jednak wraz z upływem czasu, charakter tej konwencji zaczął się zmieniać, tracąc swoje pierwotne oblicze, czego wynikiem było swego rodzaju „rozcieńczenie” związków sojuszniczych. Za pierwszy zwiastun wskazujący na kształtowanie się podstaw nowej doktryny wojennej II RP należy uznać wystąpienie szefa Sztabu Generalnego (SG) Wojska Polskiego (WP) gen. Stanisława Hallera (na odprawie inspektorów armii) 27 sierpnia 1923 r., w którym stwierdzono, że od 1 kwietnia 1924 r. Polska powinna być przygotowana do prowadzenia wojny z Niemcami lub ZSRR, bądź też obydwoma sąsiadami równocześnie (formuła tzw. dwóch wrogów „R + N”). Według tej doktryny - MW II RP miała stać na straży naszej granicy morskiej. Stawiało ją to na przegranej pozycji w stosunku do Niemiec i ZSRR, gdyż w 1923 r., jak stwierdził Józef Dyskant, państwa te dysponowały największymi flotami na Bałtyku.

Tak więc pierwotne plany zmierzające do rozbudowy floty morskiej szybko okazały się nierealne i mało przystające do ograniczonych możliwości ekonomicznych państwa. Dlatego też Kierownictwo Marynarki Wojennej (KMW), nie chcąc stracić wyszkolonych kadr, powróciło do koncepcji rozbudowy flotylli rzecznych, mających stać się swoistymi przechowalniami dla personelu morskiego (na okres kryzysu). Flotylle rzeczne traktowano także jako ważny element w ewentualnej wojnie z obu przeciwnikami: Flotylla Wiślana na kierunku zachodnim, zaś Flotylla Pińska na wschodzie. Takie rozwiązanie było zgodne z zaleceniem Ministerstwa Spraw Wojskowych, które nakazywało KMW ograniczyć budowę floty morskiej i skupić się na rozwoju flotylli rzecznych. W drugiej połowie lat dwudziestych, powiązania MW z żeglugą śródlądową oceniano następująco:

Zainteresowanie się Marynarki Wojennej wodami śródlądowymi jest tylko chwilowe i sztuczne. Flotylla Pińska potrzebną jest obecnie Marynarce Wojennej dla „Zaokrętowania” tam nadmiaru posiadanych oficerów i szeregowych, po odbyciu pływania na morzu. Flotylla ta pozostanie w rękach Marynarki Wojennej do czasu zakupienia lub wybudowania kilku dalszych statków morskich. Za lat parę Marynarka Wojenna „dla braku personelu” pozostawi Flotyllę armii lądowej².

W okresie dwudziestolecia międzywojennego, poglądy przedstawicieli polskich kół wojskowych na temat możliwości działań na froncie wschodnim,

${ }^{2}$ Centralne Archiwum Wojskowe w Wojskowym Biurze Historycznym (dalej: CAW-WBH), Akta kancelarii Sztabu Generalnego (dalej: SG), t. 56, Referat o przygotowaniu personelu dla potrzeb Wojskowej Służby Żeglugi Śródlądowej (prawdopodobnie z drugiej połowy lat dwudziestych), k. 4-5. 
ulegały znacznej ewolucji. W drugiej połowie 1926 r., inspektor armii gen. Józef Rybak przewidywał rozpoczęcie działań osłonowych na Polesiu wschodnim przez stronę radziecką po 24 godzinach od zarządzenia mobilizacji. Oceniano, że dopiero w drugiej dobie zaczną napływać na pogranicze w radzieckim okręgu zachodnim jednostki osłonowe, planowane do działań na obszarze zachodniego Polesia (polskiego). Zgodnie z posiadanym rozpoznaniem sił przeciwnika, strona polska liczyła się z możliwością działania na tym kierunku ośmiu wielkich jednostek wojskowych Armii Czerwonej, tj.: 6 i 7 Dywizji Kawalerii, 4 Samodzielnej Brygady Kawalerii, 4 i 8 Dywizji Piechoty z V Korpusu, 37 Dywizji Piechoty z XI Korpusu oraz 27 i 5 Dywizji Piechoty z IV Korpusu 3 .

Do realizacji planu osłony Polesia (pododcinka pińskiego) w końcu $1926 \mathrm{r}$. gen. J. Rybak przewidywał wydzielenie następujących sił własnych: dowództwo 5 Brygady Korpusu Ochrony Pogranicza (KOP), 15, 16, 17 Batalion KOP, dwa bataliony z 83 Pułku Piechoty, dwa bataliony z 84 Pułku Piechoty, batalion forteczny, dwie baterie artylerii oraz Flotyllę Pińską. Jako dowodzącego całością sił na tym odcinku przewidziano dowódcę 30 Dywizji Piechoty lub dowódcę piechoty dywizyjnej tego związku taktycznego. Miejscem postoju dowództwa tych sił miał być Łuniniec, a po opuszczeniu linii rzeki Cny - miasto Pińsk. Z powyższego zestawienia sił wynika, że strona polska w przyszłych działaniach bojowych na tym odcinku zamierzała wykorzystać w osłonie jednostki i pododdziały z różnych formacji (KOP, piechota, artyleria, Flotylla Pińska) ${ }^{4}$.

Trzeba podkreślić, że inspektor armii, gen. J. Rybak, był zwolennikiem dalszej rozbudowy tego typu sił mieszanych. Prezentował on bowiem stanowisko, iż wielkie jednostki wojskowe, jak dywizja piechoty czy dywizja kawalerii (brygada), nie znajdą zastosowania na obszarze Polesia. Według jego oceny - dowódca, który chciałby wykorzystać takie jednostki wojskowe na tym terenie, byłby zmuszony do ich podziału na mniejsze pododdziały i tworzenia zgrupowań taktycznych, nie dysponujących właściwym wyposażeniem i przygotowaniem do działań bojowych. W ocenie gen. J. Rybaka, do działań w trudnym terenie poleskim najlepiej nadawały się zgrupowania jednostek reprezentujących wszystkie rodzaje wojsk:

[...] w sile kilku batalionów piechoty z artylerią i kawalerią, przy czym oddziały te muszą być bogato wyposażone w sprzęt łączności: radio, konnych jeźdźców, telefon. Konieczna jest również duża ilość oddziałów technicznych, pionierów, saperów wyposażonych obficie w sprzęt techniczny ${ }^{5}$.

${ }^{3}$ CAW-WBH, Akta Generalnego Inspektoratu Sił Zbrojnych (dalej: GISZ), t. 288, Projekt gen. dyw. J. Rybaka w sprawie planu osłony odcinka poleskiego z 1 XII 1926 r., k. 1-2.

${ }^{4}$ Ibidem, t. 288, Opracowanie gen. dyw. J. Rybaka na temat możliwości działań na Polesiu z 8 X 1926 r., k. 12.

${ }^{5}$ Ibidem, k. 15-16. 
Dlatego też, do prowadzenia działań obronnych na Polesiu proponował on utworzenie specjalnych brygad mieszanych. W skład takiej jednostki miał wchodzić: batalion i szwadron KOP, dwa-trzy bataliony piechoty, bateria artylerii oraz pododdziały techniczne - pionierów, łączności i transportowe, wyposażone w odpowiedni sprzęt. Tego typu specyficzne jednostki wojskowe, w trudnych warunkach Polesia, miały stanowić przeciwwagę dla mało operatywnych radzieckich dywizji piechoty.

Z ogólnej liczby trzech brygad poleskich, które zamierzano utworzyć, dwie miały działać na północ od Prypeci, natomiast jedna na południe od tej rzeki. Ich powołanie miało nastąpić w trybie alarmowym. Brygady poleskie zamierzano podporządkować dowództwu odcinka, w skład którego miało wchodzić dowództwo 5 brygady KOP wraz z odwodem, tj. batalionami piechoty i artylerią ${ }^{6}$. Natomiast niedatowany dokument opracowany dla gen. broni Kazimierza Sosnkowskiego, w sprawie możliwości użycia i rozwinięcia sił rosyjskich na Polesiu Środkowym - wyznaczał Flotylli Pińskiej rolę łącznika pomiędzy siłami współdziałającymi na północ i południe od Prypeci. Autor wspomnianego opracowania stwierdzał, iż flotylla wyposażona w silną artylerię będzie mogła efektywnie wspierać siły działające po obu brzegach rzeki.

Uznano, że obrona sił polskich na Polesiu Środkowym była najlepszym rozwiązaniem ze wszystkich możliwych. Na jej korzyść przemawiała „ekonomiczność” położenia własnych wojsk, gdyż przesunięcie linii obronnych bardziej na zachód od tego obszaru wiązało się z możliwością użycia przez przeciwnika większych sił i środków. Przeprowadzenie działań bojowych na Polesiu dawało szansę stronie polskiej wykorzystania do obrony pasa naturalnych przeszkód wodnych i bagiennych, przy stosunkowo niedużych nakładach. Tu istniały też największe możliwości powiązania, przy pomocy sił i środków będących w dyspozycji Flotylli Pińskiej, dwóch części systemu obronnego, znajdujących się po obu brzegach Prypeci. Podsumowując, należy zgodzić się też z oceną J. Dyskanta

[...] aż do 1939 r. nasze władze wojskowe nie miały wypracowanego planu wojny, a zastępowały go doraźnie prowadzonymi studiami operacyjnymi, uzupełnianymi przez ciągle uaktualniane plany mobilizacyjne. Ze względu na to, że charakter tych studiów nie obejmował całości spraw związanych z planowaniem strategicznym i operacyjnym, często o roli flotylli nawet nie wspominano, pozostawiając ten problem zapewne zarządzeniom wykonawczym $[\ldots]^{8}$.

\section{${ }^{6}$ Ibidem, k. 16.}

7 Ibidem, t. 345, Notatka do gen. broni K. Sosnkowskiego w sprawie możliwości użycia i rozwinięcia sił rosyjskich na Polesiu środkowym (dokument niedatowany), k. 1.

${ }^{8}$ J. Dyskant, Flotylle Rzeczne i ich miejsce w planach wojennych II Rzeczypospolitej, „Przegląd Morski” 1989, nr 4, s. 76-77. 
Z tego względu, iż marszałek Józef Piłsudski nie był zwolennikiem szerokiego planowania, w konsekwencji czego - do prac związanych z opracowaniem planu wojny przystąpiono ze znacznym opóźnieniem, bo dopiero w 1935 r. Plan wojny ze Związkiem Radzieckim otrzymał nazwę „Plan Wschód”, lecz prace nad nim trwały aż do 1939 r. W dokumencie tym sformułowano zadania dla Flotylli Rzecznej w Pińsku, którą podporządkowano dowódcy Armii „Polesie” mającej działać w dorzeczu Prypeci.

\section{Charakterystyka geograficzna Polesia}

Granica polityczna pomiędzy II RP a Rosją Radziecką (ZSRR), wyznaczona traktatem ryskim z 18 marca 1921 r., podzieliła Polesie na dwie części. Część zachodnia - po polskiej stronie granicy - miała powierzchnię około 56 tys. $\mathrm{km}^{2}$, natomiast wschodnia, należąca do Rosji Radzieckiej (ZSRR) - przeszło 76 tys. km². Podział ten odpowiadał w przybliżeniu przyjętemu podziałowi geograficznemu tego obszaru, na część zachodnią i wschodnią. Porównanie wielkości obu tych terenów dawało przewagę części wschodniej, która była niemal 1,5 razy większa od części zachodniej. Zachodnie Polesie - zamieszkałe przez około 1,4 mln osób - pod względem administracyjnym należało do województwa poleskiego, a w części do województwa nowogródzkiego i wołyńskiego. Natomiast obszar Polesia wschodniego był podzielony pomiędzy Białoruską Socjalistyczną Republikę Rad (na północy) i Ukraińską Socjalistyczną Republikę Rad (na południu). Ogółem zamieszkiwało tu około 2,3 mln ludności.

Polesie było obszerną, nizinną równiną, kształtem zbliżoną do niecki. Jej rzeźba terenu nie posiadała wielkiej różnorodności form i z rzadka była tylko poprzecinana wzniesieniami. Nie miała też wyraźnie zarysowanych wyniosłości o znacznych różnicach wysokości. Prypeć wraz z Kanałem Królewskim dzieliła nizinę na dwie części: północną i południową (tzw. Polesie Litewskie i Wołyńskie). Była ona główną drogą wodną Polesia, gdyż poprzez szereg swoich dopływów wiązała cały ten obszar. Płynąc w kierunku równoleżnikowym, dzieliła Polesie na dwa obszary operacyjne (północny i południowy). Rzeka ta miała duże znaczenie dla przebiegu działań wojennych, ponieważ przecinała wszystkie połączenia kolejowe i drogowe. Ze względu na znikomą ilość stałych przepraw, pokonanie tej przeszkody wodnej stwarzało spore trudności, zwłaszcza w okresie wiosennych rozlewów. Rola Prypeci jako szlaku komunikacyjnego była częściowo uzależniona od charakteru koryta rzeki, przez co regularna żegluga rozwijała się tylko w ciągu kilku miesięcy, przy wysokim stanie wody ${ }^{9}$.

\footnotetext{
${ }^{9}$ J. Niezbrzycki, Polesie. Opis wojskowo-geograficzny, Warszawa 1930, s. 9. Vide: W. Siкorski, Polesie jako teren strategiczny. Urywki ze studiów, „Bellona” 1920, z. 3, cz. 1, s. 161-163; IDEM, Polesie
} 
O roli Polesia w przyszłych działaniach wojennych decydowało co najmniej kilka kwestii. Jednak za najważniejsze $\mathrm{z}$ nich należy uznać warunki naturalne (terenowe) tego obszaru. W pierwszej połowie XX w., pomimo rozwoju techniki wojskowej, obszar ten z punktu widzenia działań wojennych, posiadał nadal duże znaczenie. W latach dwudziestych gen. Władysław Sikorski stwierdził wręcz, że Polsce:

[...] po utracie omówionego obszaru obronnego nie pozostanie nic innego jak przeniesienie wojny do wnętrza kraju i szukanie rozstrzygnięcia wojny nad Wisła, to znaczy odtwarzanie kampanii roku 1794, 1809, 1830-1831, 1914 oraz wysiłku z sierpnia 1920 r., który nas kosztował tyle krwi $[\ldots]^{10}$.

W okresie międzywojennym, Polesie nadal stanowiło znaczącą przeszkodę, zarówno dla wojsk działających na kierunku wschód-zachód, jak i północ-południe. Terytorium II RP oddzielał od Związku Radzieckiego tzw. wielki pas przedni, stanowiący wstępny obszar operacyjny na wypadek działań wojennych pomiędzy Polską a jej wschodnim sąsiadem. W skład tego obszaru wchodziły wschodnie rejony Polski - oparte od północy na Dźwinie, a od południa na Dniestrze. Na zachodzie, jego granicę stanowiła linia Bugu, Leśnej i Narwi, natomiast na wschodzie granica ta podchodziła pod Dniepr. Przewidywano, iż na tym terenie będą przeprowadzane wszelkie działania zaczepne i obronne, jak i ostateczne przegrupowania i koncentracje sił. Cały ten obszar przecinała biegnąca z północy na południe granica polsko-radziecka mająca $1412 \mathrm{~km}$ długości, podzielona pod względem administracyjnym i politycznym na dwa odcinki: białoruski $(807 \mathrm{~km})$ i ukraiński $(603 \mathrm{~km})$.

Warunki terenowe i możliwości przewozowe rzutowały na odmienne właściwości operacyjne obszaru północnego, środkowego i południowego. Ich charakter zadecydował o powstaniu terminu „dwóch teatrów wojen”: północno-wschodniego i południowo-wschodniego. Obszar północno-wschodni (zwany też białoruskim, bądź białorusko-litewskim) analizowano jako domniemany teren głównych radzieckich działań wojennych na wschodzie. Przemawiała za tym możliwość wykorzystania linii komunikacyjnych do szybkiego przerzutu wojsk i ich sprawnego zaopatrywania z centralnych terenów Związku Radzieckiego. Na obszarze tym, sieć kolejowa zbiegała się w trzech dużych węzłach kolejowych: Smoleńsku, Witebsku i Orszy ${ }^{11}$. Natomiast obszar południowo-wschodni był ograniczony od wschodu linią Dniepru, stanowiącą poważną przeszkodę, zamykającą

jako węzeł naszego frontu wschodniego, „Bellona” 1924, z. 1, s. 9-14; Encyklopedia wojskowa, t. VI, red. O. LAskowski, Warszawa 1937, s. 521-522.

${ }^{10}$ W. Sikorski, op. cit., s. 31. Vide: W. Mondalski, Polesie. Zarys wiadomości ogólnych, cz. 1, Brześć nad Bugiem 1927, s. 21-22; J. NiezBrzycKi, op. cit., s. 387-388.

${ }^{11}$ W. SiKorski, op. cit., s. 9-32; J. NieZbrZYCKI, op. cit., s. 385-391. 
wszystkie szlaki dofrontowe. Jednakże rzeka ta nie posiadała dogodnego i naturalnego przejścia, jak to miało miejsce na obszarze północno-wschodnim. Wzdłuż Dniepru, w latach dwudziestych postępowała intensywna rozbudowa połączeń i węzłów komunikacyjnych. Tu znajdowały się największe ośrodki przemysłowe i zaopatrzeniowe ${ }^{12}$.

Z punktu widzenia działań wojskowych i panujących warunków (terenowych, komunikacyjnych, narodowościowych), na obszarze polskiego Polesia wyodrębniano w tym czasie trzy zasadnicze części: zachodnią - ograniczoną od południa rzeką Prypecią, na wschodzie rzeką Jasiołdą, a na północy drogą łączącą Brześć z Berezą Kartuską, północno-wschodnią - leżącą na wschód od rzeki Jasiołdy i na północ od rzeki Prypeci oraz południową - leżącą na południe od Prypeci, składającą się z dwóch obszarów położonych na wschód i zachód od rzeki Horyń. Ponadto w pasie przygranicznym (między granicą państwa a linią kolejową) można było wyodrębnić część środkową, obejmującą strefę zalewową Prypeci i dwa korytarze lądowe biegnące między wspomnianą depresją a bagnami Olmańskimi i bagnami Hryczyn. Część ta, pod względem operacyjnym, stanowiła wyodrębniony odcinek ${ }^{13}$.

Polesie, dzięki swojemu centralnemu położeniu, a także właściwej sobie specyfice, stanowiło odrębny obszar operacyjny i przeszkodę naturalną, oddzielającą obszar północno-wschodni od południowo-wschodniego. Kotlina poleska charakteryzowała się specyficznym kształtem. W miarę przemieszczania się ku wschodowi, stawała się ona coraz szersza i o ile na linii Bugu jej szerokość (w kierunku równoleżnikowym) wynosiła zaledwie $110 \mathrm{~km}$, o tyle po przeciwległej stronie - na linii Dniepru - zwiększała się do $400 \mathrm{~km}$. Ten kształt kotliny wpływał na znaczne odchylenie się we wschodniej części wszystkich szlaków dofrontowych, biegnących obrzeżem Polesia, od głównej osi strategicznej tego obszaru. Osią tą była linia pomiędzy Brześciem n. Bugiem a Łojowem $(430 \mathrm{~km})$, która mniej więcej pokrywała się z linią Muchawiec-Kanał Królewski-Prypeć ${ }^{14}$.

Dla przeprowadzenia operacji wojskowych na terenie Polesia największe znaczenie miał układ przeszkód naturalnych w postaci: rzek i ich dolin, kompleksów bagien i lasów, a także sieci połączeń komunikacyjnych. Analiza rozmieszczenia elementów mogących wpływać na przebieg działań wojennych na tym obszarze pozwala zauważyć, że były one położone w środkowej części tego terenu, mniej więcej pomiędzy linią biegnącą ze wschodu na zachód i przechodzącą przez Pińsk, a linią wzdłuż rzeki Ptycz i Uborć. Znajdowały się tu liczne i zwarte kompleksy bagienne oraz podmokłe lasy poprzecinane dopływami Prypeci, płynącymi

12 J. NieZBrZYCKI, op. cit., s. 391-394.

${ }^{13}$ CAW-WBH, Akta GISZ, t. 307, Pismo inspektora armii gen. K. Sosnkowskiego do GISZ w sprawie przeprowadzenia studiów na obszarze Polesia z 6 V 1931 r., k. 6-7.

${ }^{14}$ J. NieZBRZYCKI, op. cit., s. 395, 400. 
przeważnie w kierunku południowym. Sieć połączeń komunikacyjnych była tu bardzo rzadka, a przeprawy przez rzeki nieliczne. Tereny leżące na wschód i zachód od tego pasa były bardziej dostępne. $Z$ wojskowego punktu widzenia, na uwagę zasługiwał też równoleżnikowy podział terenu Polesia. Podział ten był uwarunkowany szeroką i bagnistą doliną Prypeci, która wraz z Piną i Kanałem Królewskim przecinała cały ten obszar, dzieląc go na dwie części - północną i południową. Wzdłuż tej osi znajdowały się najważniejsze węzły komunikacyjne: Brześć n. Bugiem, Kobryń, Pińsk, Dawidgródek, Kalenkowicze i Mozyrz.

Dużą rolę dla działań wojennych prowadzonych na Polesiu miał, w większości południkowy, kierunek dopływów Prypeci. Przebiegające prostopadle do osi operacji wojskowych rzeki mogły być wykorzystane jako linie obronne. Jednak najważniejszymi przeszkodami na Polesiu były kompleksy bagienne. Poza nielicznymi sztucznymi drogami i rzadkimi piaszczystymi wyspami - były one trudne do pokonania. Zmuszały bowiem przeciwnika do korzystania $\mathrm{z}$ wąskich i niedogodnych przejść, łatwych do zablokowania, przy użyciu niewielkich oddziałów wojska. O dostępności terenu Polesia decydowała też pora roku i ilość opadów atmosferycznych. Podczas intensywniejszych deszczów - zwłaszcza wiosną i jesienią - większość poleskich bagien stawała się całkowicie niedostępna ${ }^{15}$.

W połowie lat dwudziestych, polskie dowództwo nadal przypisywało Polesiu szczególną rolę. Gen. J. Rybak tak oceniał znaczenie tych terenów:

Posiadanie w swych rękach Polesia pozwala na swobodne manewrowanie i przerzucanie sił po najkrótszych liniach z południowego na północny teren działań wojennych i odwrotnie. Kto trzyma silne Polesie ten ma swobodę działań na wschodzie [...] nade wszystko daje możliwość dowolnego w czasie i przestrzeni, przy szukaniu rozstrzygnięcia na północy, czy na południu uderzenia na flankę przeciwnika, przy czym tyły i flanki tej uderzeniowej grupy byłyby chronione przez teren Polesia $[\ldots]^{16}$.

Specyfikę tego rejonu w 1929 r. gen. J. Rybak charakteryzował następująco:

$\mathrm{Na}$ Polesiu bowiem teren musi być zanalizowany z punktu widzenia trzech pór roku, w ciągu których jeden i ten sam teren przybiera zupełnie inną fizjognomię i ma najzupełniej inną wartość, jeśli chodzi o działania wojenne, bądź zaczepne bądź obronne. Dość wskazać, że bardzo liczne obszary Polesia na wiosnę zalane wodą są nie do przebycia poza łodziami. Latem gdy wiosenne wody opadną, te same obszary bywają zazwyczaj trudne do przebycia nawet dla pieszych skutkiem zabagnienia, wyjątek może stanowić bardzo suche lato, natomiast w zimie gdy chwycą mrozy, szczególnie przed dużymi opadami śniegowymi nawet naj-

15 Ibidem, s. 400-403.

${ }^{16}$ CAW-WBH, Akta GISZ, t. 288, Opracowanie gen. J. Rybaka na temat możliwości działania na Polesiu z 8 X 1926 r., k. 7-8. 
większe kompleksy latem trudno dostępnych bagien, pokrywają się licznymi drogami zimowymi [...] i są zdatne do posuwania się wszelkich rodzajów broni wraz z taborami $[\ldots]^{17}$.

Natomiast w końcu 1931 r., gen. K. Sosnkowski, tak pisał o znaczeniu wojskowym Polesia:

Mając jedynie na względzie rolę i znaczenie obszaru Polesia w przyszłych działaniach wojennych trzeba przyznać, że bezsprzecznie najdogodniej byłoby zachować obecny charakter tego obszaru, z góry przesądzając na niekorzyść sprawę jego melioracji i osuszania. Polesie bowiem stanowi 1/3 części naszego przyfrontowego obszaru wschodniego [...]. Ponadto biorąc pod uwagę rozciągłość przestrzenną naszej wschodniej strefy zagrożenia w stosunku do ograniczonych sił i środków jakie możemy przeciwstawić naszemu przeciwnikowi, dzisiejszy charakter bezdroży poleskich daje nam możliwość uzyskania znacznej oszczędności sił, przeznaczonych do obrony ${ }^{18}$.

Możliwości przeprowadzenia działań bojowych na tym obszarze gen. K. Sosnkowski w połowie 1933 r. oceniał następująco:

Wzdłuż obu krawędzi doliny Prypeci biegną na północ i południe dwa trakty (trakt Lenin-Łuniniec-Pińsk) prowadzące w terytorium przeciwnika, w serce Polesia. Wzdłuż tych traktów lub w ich bezpośrednim pobliżu, siłą rzeczy rozwinąć się muszą główne działania wojenne, na terytorium środkowego Polesia ${ }^{19}$.

Za główny cel, obowiązujący w polityce obronnej państwa polskiego na początku lat trzydziestych, koła wojskowe uważały zachowanie w nienaruszonym stanie określonych obszarów (bądź nawet podniesienie ich wartości obronnej). $\mathrm{Na}$ tzw. obszarach zastrzeżonych wszelkie prace melioracyjne przed ich rozpoczęciem musiały być uzgadniane z władzami wojskowymi, zaś gospodarka leśna nie mogła powodować osuszania ziemi. Obszary zastrzeżone znajdowały się w województwach: tarnopolskim, wołyńskim, poleskim, nowogródzkim, wileńskim, białostockim i warszawskim. Na Polesiu, granica strefy zastrzeżonej przebiegała przez następujące miejsca: Filipowicze-Mołwidy-Domanowo-Iwacewicze-Kosów-Haleny-Kamieniec Litewski-rzekę Leśna-Brześć nad BugiemKodeń-Domaczów-Włodawa-Uhrusk-Kowel-Hołoby-Rożyszcze ${ }^{20}$.

${ }^{17}$ Ibidem, t. 298, Pismo gen. J. Rybaka w sprawie studiów terenu oraz organizacji obrony odcinka poleskiego z 15 X 1929 r., k. 3.

${ }_{18}$ Ibidem, t. 131, Pismo gen. K. Sosnkowskiego do szefa SG z listopada 1931 r., k. 1.

${ }_{19}$ Ibidem, t. 1939, Wytyczne gen. K. Sosnkowskiego w sprawie wyszkolenia artyleryjskiego Flotylli Pińskiej z sierpnia 1933 r., k. 1-2.

${ }^{20}$ Ibidem, t. 131, Postulaty wojenne w zakresie melioracji, k. 15-16 oraz Pismo szefa SG gen. J. Gąsiorowskiego do Ministerstwa Rolnictwa i Reform Rolnych z września 1939 r., k. 1. 
Jednak dla funkcjonowania Flotylli Pińskiej najistotniejsze znaczenie na tym obszarze posiadały rzeki, porty i przystanie wodne dorzecza Prypeci. Jak stwierdził J. Dyskant - z 34 dopływów Prypeci zaledwie 6 (18\%) nadawało się do żeglugi: Jasiołda z Piną, Śmierć, Łań (tylko przy wysokiej wodzie), Słucz Północna, Styr (Prostyr) oraz Horyń. Jasiołda miała 236 km długości i była dostępna dla żeglugi w dolnym biegu od Kanału Ogińskiego; Pina, licząca 83 km, była najważniejszym jej dopływem, od połączenia z Kanałem Królewskim była spławna i żeglowna dla statków o zanurzeniu do 0,9 m; Śmierć liczyła 38 km i wpadała do Prypeci pod m. Przewóz Łachewski, rzeka ta była spławna i żeglowna od m. Łachwa dla statków o niewielkim zanurzeniu; Łań to rzeka o długości $185 \mathrm{~km}$, a żegluga na niej była możliwa tylko przy wysokim stanie wody do $\mathrm{m}$. Sienkiewicze; Słucz Północna liczyła sobie 197 km długości, rzeka była spławna od m. Słuck, a żeglowna od m. Lenin; Styr miał 482 km długości i był spławny na całej długości, natomiast żeglowny tylko na Prostyrze; Horyń był najdłuższą rzeką, ponieważ liczył $572 \mathrm{~km}$, z tego $150 \mathrm{~km}$ przebiegało poza granicami II RP. Na rzece była możliwa żegluga w jej środkowym biegu, jednak w znacznym zakresie utrudniały ją liczne jazy, zastawki i młyny wodne. Od stacji kolejowej Horyń rzeka była dostępna dla statków o zanurzeniu do $0,7 \mathrm{~m}^{21}$.

Natomiast do najważniejszych portów i przystani leżących w dorzeczu Prypeci należały po stronie II RP: Pińsk nad Piną, Dawidgródek nad Horyniem i Brześć nad Bugiem. Natomiast po stronie radzieckiej były to: Turów, Mozyrz i Czarnobyl, leżące nad Prypecią. W tym zestawieniu portów i przystani największe znaczenie miał Pińsk, położony w centrum tzw. węzła wodnego nad Piną. W 1938 r. posiadał on 35960 mieszkańców i stanowił ważny węzeł dróg gruntowych do Brześcia, Równego, Prużan, Nieświeża i Łunińca. Pińsk posiadał także dużą stację kolejową na linii Brześć-Łuniniec oraz największy port rzeczny (handlowy) Polesia Zachodniego. Był też główną bazą Flotylli Pińskiej, posiadającej tu własną stocznię i Warsztaty Portowe MW22. Dawidgródek liczył w 1927 r. 13500 mieszkańców i był jednym z największych miasteczek Polesia zachodniego. Był również miejscem dogodnej przeprawy przez rzekę Horyń, a także węzłem drogowym. Mógł stanowić wysuniętą bazę dla jednostek polskiej Flotylli Pińskiej. Kolejnym ważnym miastem był Brześć leżący przy ujściu rzeki Muchawiec do Bugu. Miasto w 1927 r. liczyło 46000 mieszkańców. Tu mieściło się Dowództwo Okręgu Korpusu nr IX. Był to także ważny węzeł drogowy i kolejowy. Istniał tu również duży port rzeczny, który mógł być wykorzystywany jako baza tyłowa dla Flotylli Pińskiej i Flotylli Wiślanej. Z kolei leżący po stronie radzieckiej Turów posiadał dużą przystań rzeczną i był ważnym punktem handlowym Polesia Wschodniego.

${ }^{21}$ J. Dyskant, Flotylla Rzeczna..., s. 65-66.

22 I. Bieniecki, Port Wojenny Flotylli Rzecznej w Pińsku 1919-1939, „Przegląd Morski” 1992, nr 3, s. 41-52. 
W 1927 r. liczył 5383 mieszkańców, a na wypadek wojny mógł odgrywać rolę wysuniętej bazy radzieckiej Flotylli Dnieprzańskiej. Również Mozyrz dysponował dużą przystanią rzeczną. Był także ważnym węzłem kolejowym. W $1927 \mathrm{r}$. liczył 9623 mieszkańców i wciąż intesywnie się rozbudowywał jako ośrodek przemysłowy. W przypadku działań wojennych mógł również pełnić rolę wysuniętej bazy radzieckiej Flotylli Dnieprzańskiej. Także Czarnobyl był ważnym węzłem drogowym. Miasto posiadało przystań wodną na Dnieprze. Funkcjonowały tu duże zakłady remontowe taboru wodnego oraz składy drewna opałowego dla statków. W działaniach wojennych mógł także pełnić rolę wysuniętej bazy dla Flotylli Dnieprzańskiej. Z powyższego zestawienia wynika, iż porty i przystanie na Polesiu odgrywały znaczącą rolę jako ważne punkty komunikacyjne. $\mathrm{W}$ istniejących $\mathrm{w}$ pierwszej połowie XX w. warunkach - porty i przystanie rzeczne funkcjonowały $\mathrm{z}$ reguły $\mathrm{w}$ rejonach przepraw przez rzeki. Do istniejącego układu portów i przystani starano się też dopasować sieć drogowo-kolejową ${ }^{23}$.

Ze względu na graniczne położenie Polesia, rozwój dróg wodnych, a co za tym szło i żeglugi, był uzależniony od ułożenia stosunków handlowych ze Związkiem Radzieckim, co w latach dwudziestolecia międzywojennego nie zostało rozwiązane. Dlatego też, według danych z 1934 r., w dorzeczu Prypeci żeglownych było tylko $2044 \mathrm{~km}$ rzek i kanałów - z tego do żeglugi wykorzystywano zaledwie $874 \mathrm{~km}$, a do spławiania drewna $1517 \mathrm{~km}$. Rozwojowi większego ruchu żeglugowego nie pomagała słabość ekonomiczna Polesia - w konsekwencji dominowała tu żegluga towarowa, a zasadniczym rodzajem transportu był spław drewna. Po stronie polskiej słaba była również żegluga pasażerska, chociaż pod koniec lat trzydziestych XX w. uległa ona poprawie, ze względu na rozwój ruchu turystycznego. W dorzeczu Prypeci w tym czasie funkcjonowało 6 regularnych linii żeglugowych, w ramach których pływało kilkanaście statków, należących do kilku niewielkich prywatnych armatorów. Obsługiwały one linie żeglugowe o łącznej długości 388 km (okresowo - 842 km). Jak obliczył J. Dyskant, w końcu 1932 r. na wschodnich drogach wodnych II RP (Prypeć, Niemen, Dźwina) pływało ogółem 30 statków z własnym napędem, o łącznej mocy maszyn $1702 \mathrm{KM}$ oraz 59 barek bez napędu. Stanowiło to około 17\% ogółu ówczesnego taboru rzecznego w Polsce. Wykorzystywane w tym czasie do żeglugi rzecznej jednostki pływające były zbudowane w Rosji na przełomie XIX i XX w. i posiadały słabe parametry techniczne, konstrukcyjne i eksploatacyjne. W przypadku mobilizacji dla potrzeb polskiej flotylli MW tabor ten nie przedstawiał sobą większej wartości²4.

\footnotetext{
${ }^{23}$ J. Dyskant, op. cit., s. 71-72.

${ }^{24}$ Statki pasażerskie pływały w tym czasie na następujących trasach żeglugowych: Pińsk-Stare Konie nad Prostylem - 40 km (okresowo do Łucka 280 km), Pińsk-Dawidgródek - 119 km, Dawidgródek-stacja kolejowa Horyń - 59 km, Pińsk-Lubieszow nad Stochodem - 88 km, Pińsk-Telechany nad Kanałem Ogińskiego - 82 km, Pińsk-Brześć (okresowo) - 214 km (ibidem, s. 68-70).
} 


\section{Możliwości prowadzenia działań przez Flotyllę Pińską w ocenach dowódców i przełożonych}

Intensywna rozbudowa Flotylli Pińskiej rozpoczęła się w 1927 r., w związku z ponownym odtworzeniem radzieckiej Flotylli Dnieprzańskiej. Jedyna już wówczas flotylla rzeczna w polskiej MW (dowodzona od 25 lutego 1927 r. przez kmdr. ppor. Witolda Zajączkowskiego ${ }^{25}$ ), zgodnie z planem działania na wschodzie, miała wejść w skład Armii „Polesie”. Do jej głównych zadań należało: zwalczanie flotylli rzecznej nieprzyjaciela, współdziałanie z wojskami lądowymi w pasie nadrzecznym, niszczenie fortyfikacji brzegowych przeciwnika, zwalczanie jego komunikacji rzecznej oraz osłanianie własnych transportów ${ }^{26}$. Na rolę Flotylli Pińskiej w działaniach na Polesiu zwracał w 1927 r. uwagę wspomniany już gen. J. Rybak:

W trudnych warunkach działań na terenie poleskim gdzie punktem wyjścia powinno być użycie jak najmniejszej ilości sił dla utrzymania frontu bojowego Flotylla Pińska odgrywać będzie bardzo poważną rolę. Teren poleski utrudnia bowiem i ogromnie ogranicza użycie artylerii, której ogień na całym szeregu obszarów może być dany jedynie $\mathrm{z}$ dział umieszczonych na statkach. $\mathrm{Z}$ tego więc względu Flotylla Pińska jest właściwie rezerwuarem ognia artylerii na głównych arteriach rzecznych Polesia. Przez umieszczanie dział na statkach pancernych oraz wyposażenie tych ostatnich w dużą ilość broni maszynowej powstają jakby forty pancerne, szybko poruszające się w trudnym terenie poleskim, a potężnie wyposażone w środki walki ogniowej (odwód ogniowy). Dzięki odpowiedniemu wyposażeniu w organa zwiadowcze i przesłaniające jak to motorówki, płatowce, hydroglisery itp. dzisiejsza Flotylla Pińska stanowi obecnie cenny element bojowy na dorzeczu Prypeci. Może bowiem ona z jednej strony niemal samodzielnie walczyć w obszarach gdzie nie jest w stanie z racji błot i bezdroży przeniknąć własna piechota i artyleria, $\mathrm{z}$ drugiej strony ten potężny rezerwuar ogniowy może wspierać działania własnej piechoty, szczególnie jeśli idzie o dostarczenie jej wsparcia artylerii, która o zaprzęgu konnym nie zawsze będzie mogła na Polesiu poruszać się za piechotą [...]. Reasumując: dla działań na Polesiu Flotylla Pińska jest pierwszorzędnym elementem walki, jest typową bronią walczącą, gdyż jej główne zadania polegają na bezpośrednim udziale w bitwie, czy to walcząc samodzielnie czy też wspierając własną piechotę. Jej zadania inne, pomocnicze jak na przykład transportowe są bardzo ograniczone (Flotylla Pińska nie ma specjalnych

${ }^{25}$ I. BIENIECKI, Komandor Witold Zajączkowski - dowódca, nauczyciel i wychowawca marynarskich kadr (1892-1997), [w:] Moja droga na morze. Jubileuszowe wspomnienia absolwentów oksywskiej Alma Mater, red. A. Drzewiecki, B. Zalewski, Gdynia 2004, s. 7-35; idem, Komandor Witold Zajączkowski (1892-1977) - dowódca Flotylli Pińskiej, „Przegląd Morski” 1990, nr 4, s. 58-62; M. Herma, „Książę Polesia”. Komandor Witold Zajączkowski. Ostatni dowódca Flotylli Rzecznej Marynarki Wojennej, [w:] Zapomniane bandery. Flotylle rzeczne II Rzeczypospolitej, red. S. JANUszewSKI, Wrocław 2019, s. 151-162; http://www.polskipetersburg.pl/hasla/zajaczkowski-witold [dostęp: $13 \mathrm{~V} 2019$ r.].

${ }^{26}$ I. Bieniecki, Flotylla Rzeczna..., s. 58-59. 
transportów gdyż takowe wchodzą w skład żeglugi śródlądowej, związanej jak wszystkie inne służby transportowe z oddziałem IV i mogą być stosowane jedynie na polu walki dla doraźnego przewiezienia kilku jednostek piechoty [...]. Jej zadanie jest bojowe, a nie techniczne. Nie przeszkadza to bynajmniej, że w niektórych wypadkach część Flotylli może zapewnić pomoc przy budowie mostów ${ }^{27}$.

Interesujące poglądy na temat wykorzystania flotylli przedstawił w 1929 r. - w dyskusji, jaka się wywiązała na ten temat - gen. dyw. Juliusz Rómmel. Według niego, dla obrony Polesia w czasie przyszłych działań wojennych Polska była w stanie wyznaczyć pododdziały przedstawiające siłę jednej dywizji piechoty. W takiej sytuacji, Flotylla Pińska posiadająca w tym czasie artylerię składającą się z 26 dział kal. $75 \mathrm{~mm}$ i $100 \mathrm{~mm}$ oraz 15 działek kal. 37 i $47 \mathrm{~mm}$, stanowiła liczącą się siłę bojową. W ocenie generała, w takich warunkach operacyjnych i terenowych, nie należało używać flotylli do wykonywania wypadów na tyły nieprzyjaciela (jak to przewidywał gen. J. Rybak), ponieważ wszelkie wypady zagrażały głównie własnym liniom komunikacyjnym. Według gen. J. Rómmla, zasadniczym zadaniem flotylli miało być współdziałanie z oddziałami lądowymi, które gwarantowały zabezpieczenie jej dróg komunikacyjnych i odwrotowych. Możliwości prowadzenia działań skrzydłowych przez flotyllę na Polesiu generał oceniał jako utrudnione, co świadczyło o jego realistycznym spojrzeniu na to zagadnienie. Decydujący wpływ miał na to poziom wody, który ograniczał pływanie monitorów, zasadniczo do rzeki Prypeć, bez możliwości pływania na jej dopływach. Dlatego w przyszłej walce za decydujące uznał on właściwe wykorzystanie ognia artyleryjskiego flotylli ${ }^{28}$.

Natomiast KMW pod koniec lat dwudziestych prezentowało pogląd, iż Flotylla Pińska nie może być jednostką, której rola ograniczałaby się do funkcji transportowych. W jednym z dokumentów znajdujących się w Centralnym Archiwum Wojskowym w Warszawie, stanowisko w powyższej kwestii przedstawiono następująco:

Flotylla Pińska powinna mieć taką organizację i wyszkolenie aby mieć możność walki jednocześnie na rzece i na lądzie w rejonie Polesia. Co zaś dotyczy użycia Flotylli jako środka przewozowego to może to mieć miejsce w sensie taktycznym tj. dostarczenia niewielkich oddziałów wojska do pewnych punktów, gdzie tego wymagają konieczności operacyjne w danej chwili. Transportowanie większych ilości wojsk w celach strategicznych (nie dla bezpośredniej współpracy z Flotyllą) byłoby skuteczniej i taniej zapewnione przez statki cywilne niż użycie do tego celu Flotylli ${ }^{29}$.

${ }^{27}$ CAW-WBH, Akta Kierownictwo Marynarki Wojennej (KMW), t. 443, Pismo gen. J. Rybaka do GISZ z 5 XII 1927 r., k. 1-2.

${ }^{28}$ CAW-WBH, Akta GISZ, t. 1933, Pismo gen. J. Rómmla do GISZ z 29 X 1929 r., k. 1-2.

${ }^{29}$ CAW-WBH, Akta kancelarii SG, t. XLVII, Notatka do Oddziału I SG zawierająca stanowisko KMW z 9 XI 1929 r., k. 1. 
Z ograniczonych możliwości działania Flotylli Pińskiej zdawał sobie również sprawę dowódca Okręgu Korpusu nr IX w Brześciu n. Bugiem, gen. bryg. Mieczysław Ryś-Trojanowski. Mając na uwadze ich poszerzenie, skierował w $1931 \mathrm{r}$. pismo do szefa komunikacji wojskowej w Sztabie Generalnym (SG), w którym zawarł szereg postulatów dotyczących uregulowania dróg wodnych na obszarze Polesia. Za najważniejsze zadanie uznał udrożnienie drogi wodnej na trasie rzeka Pina-Kanał Królewski-rzeka Muchawiec, dzięki czemu jednostki pływające flotylli mogłyby w każdej chwili przepłynąć z Pińska do Brześcia n. Bugiem. W jego ocenie, obecna baza flotylli była położona zbyt blisko granicy, co nie stanowiło dla niej dostatecznego zabezpieczenia w przypadku konieczności wycofania własnych sił na zachód od Pińska. Przemieszczenie się jednostek pływających flotylli na tym kierunku było bowiem możliwe tylko w czasie kilku miesięcy wiosennych, przy wysokim stanie wody. W pozostałym okresie, z powodu małej ilości wody, bądź zamarzania rzek, przepływ jednostek flotylli tą drogą był niemożliwy. Przeprowadzenie regulacji drogi wodnej na trasie Pińsk-Brześć n. Bugiem zapewniłoby swobodne pływanie jednostek flotylli przez cały okres wiosenno-letnio-jesienny. Realizacja tego przedsięwzięcia pozwoliłaby na zabezpieczenie flotylli w przypadku niepowodzenia $\mathrm{w}$ działaniach wojennych w rejonie Pińska, a także umożliwiłaby przerzucenie i wykorzystanie jednostek pływających flotylli na innych rzekach. Dlatego też, proponował rozbudować bazę zimową flotylli w Brześciu n. Bugiem, bowiem w przypadku zimowej ofensywy wojsk rosyjskich w kierunku Pińska, przy zamarzniętych rzekach, flotylla nie mogłaby wykonać zadań, do których została przeznaczona. Natomiast w sytuacji, gdyby zimowanie flotylli odbywało się w Brześciu n. Bugiem, byłaby ona w znacznie lepszym położeniu (mimo unieruchomienia przez lody), ze względu na większą odległość od granicy. Zgodnie z tą koncepcją, Brześć n. Bugiem spełniałby rolę bazy tylko w czasie zimy, bowiem z chwilą puszczenia lodów jednostki pływające wracałyby do swojej bazy letniej w Pińsku (uregulowaną drogą wodną). W celu rozszerzenia obszaru operacyjnego działania flotylli, gen. M. Ryś-Trojanowski sugerował też potrzebę uporządkowania śluz na rzece Szczarze oraz rozbudowę Kanału Ogińskiego, którego w aktualnym stanie monitory nie mogły pokonać. Jednak realizacja tych przedsięwzięć była uzależniona od wielkości środków finansowych przeznaczonych na te cele ${ }^{30}$.

Jak wcześniej wspomniano, działania flotylli były uzależnione również od panujących na Polesiu warunków wodnych. Na terenach położonych na wschód od Pińska flotylla mogła działać bez problemów tylko w okresie nawigacyjnym, tj. od połowy kwietnia do listopada (około 8 miesięcy). Utrudnienia w nawigacji okrętów i statków flotylli na rzekach występowały najczęściej w okresie niskiego

${ }^{30}$ CAW-WBH, Akta GISZ, t. 1929, Pismo dowódcy Okręgu Korpusu nr IX gen. bryg. M. Rysia-Trojanowskiego do szefa komunikacji wojskowej SG z 11 V 1931 r., k. 1-2. 
stanu wody, który trwał z reguły od 15 lipca do 15 września każdego roku (około 3 miesiące), tj. w czasie najbardziej sprzyjającym prowadzeniu działań bojowych przez wojska lądowe. Natomiast przepłynięcie największych jednostek pływających flotylli (o największym zanurzeniu) z Prypeci na Wisłę - było ograniczone i możliwe tylko w okresie wysokiego stanu wody, od 15 kwietnia do 30 maja (około 1,5 miesiąca) ${ }^{31}$.

Gen. K. Sosnkowski dostrzegł w połowie 1933 r. także znaczne możliwości oddziaływania flotylli na przebieg działań wojennych na Polesiu, dzięki posiadanej artylerii. Za główne zadania tej jednostki uznał opanowanie szlaków żeglugi rzecznej i zwalczanie sił nawodnych nieprzyjaciela, a także zapewnienie łączności taktyczne-operacyjnej obu brzegów dorzecza Prypeci i współdziałanie ogniowe artylerii flotylli z oddziałami lądowymi. Warto dodać, iż w Regulaminie bojowym Flotylli Rzecznej obowiązującym od 1934 r., ustalono następujące główne zadania tej jednostki: panowanie nad rzekami, współdziałanie $\mathrm{z}$ oddziałami wojsk lądowych oraz transportowanie pododdziałów wojsk lądowych ${ }^{32}$. Jednocześnie, za obszar działania jednostki rzecznej uznano śródlądową sieć wodną oraz teren do niej przylegający, nad którym można było sprawować kontrolę poprzez artylerię flotylli33.

W połowie lat trzydziestych działanie flotylli nadal uzależniano od przebiegu przyszłych operacji wojskowych na Polesiu. Mogła być ona wykorzystywana do prowadzenia następujących działań: walki nawodnej mającej na celu zniszczenie flotylli przeciwnika, współdziałania z własnymi siłami lądowymi poprzez wspieranie ich na lądzie ogniem artylerii (zarówno podczas natarcia, jak i obrony), ubezpieczania sił na lądzie w czasie odwrotu, wysadzania desantu i współdziałania w czasie akcji przerzucania oddziałów lądowych przez rzeki wraz z obroną przepraw, niszczenia umocnień nieprzyjaciela w pobliżu rzek i pasa przyległego, niszczenia linii komunikacyjnych nieprzyjaciela na rzekach oraz ubezpieczania własnych linii komunikacyjnych na wodach śródlądowych ${ }^{34}$.

Przegląd zaprezentowanych powyżej stanowisk na temat możliwości wykorzystania Flotylli Pińskiej w działaniach bojowych pozwala dostrzec przynajmniej jeden istotny fakt, który przy rozważaniu tych działań brano pod uwagę, choć tylko w ograniczonym zakresie. Chodzi mianowicie o utrudnienia w przemieszczaniu się jednostek pływających, wynikające z niskiego stanu wody w rzekach w okresie lata i ich zamarzania w czasie zimy. Wszyscy wojskowi decydenci mający wpływ na ustalenia dotyczące Flotylli Pińskiej, opowiadali się za wariantem

31 CAW-WBH, Akta kancelarii SG, t. 50, Referat Oddziału III SG z 1 XII 1932 r., k. 1-3.

32 Archiwum Maryarki Wojennej w Gdyni (obecnie w CAW-WBH), sygn. nr 290/15, Regulamin bojowy Flotylli Rzecznej, cz. 1, Warszawa 1934, k. 3 (odpis w zbiorach autora).

${ }_{33}$ CAW-WBH, Akta GISZ, t. 1939, Wytyczne gen. K. Sosnkowskiego w sprawie wyszkolenia artyleryjskiego Flotylli Pińskiej z sierpnia 1933 r., k. 1-2.

${ }^{34}$ CAW-WBH, Akta szefa SG, t. XXIV, Opracowanie w sprawie flotylli rzecznej z 21 X 1936 r., k. 6-7. 
bardzo optymistycznym i byli skłonni widzieć jej decydującą rolę w działaniach bojowych, bez względu na występujące warunki wodne i rozwój innych rodzajów wojsk. Można przypuszczać, że o takim mało krytycznym podejściu do tematu flotylli rzecznych w okresie międzywojennym ze strony czołowych wojskowych II RP zadecydowała ich fascynacja nowoczesną techniką i nowymi środkami walki. Flotylle rzeczne, na tle rodzących się wówczas w innych państwach koncepcji zastosowania różnych rodzajów wojsk szybkich na polach przyszłej wojny, nie wzbudzały tylu kontrowersji. Mimo to, już wówczas zdawano sobie sprawę z ograniczonych możliwości wykorzystania jednostek rzecznych w czasie potencjalnej wojny. Jednak przeważyły wciąż doświadczenia wyniesione z wojny z Rosją bolszewicką, które zdaniem wielu decydentów - potwierdziły potrzebę utrzymania Flotylli Pińskiej w jej dotychczasowym kształcie. Dopiero rok 1939 dowiódł, iż w nowoczesnej wojnie flotylle rzeczne mogą być wykorzystane tylko w bardzo ograniczonym zakresie.

\section{Parametry techniczne jednostek pływających i wynikające stąd ograniczenia}

W latach 1918-1939 jednostki pływające funkcjonujące w ramach flotylli rzecznych, zarówno w Polsce, jak i na świecie, zaliczano do kilku podstawowych typów, takich jak: monitory, statki pancerne, trałowce rzeczne, motorówki uzbrojone i ślizgacze oraz pomocnicze jednostki pływające.

Największymi i najsilniej uzbrojonymi okrętami pływającymi po wodach śródlądowych były monitory. $\mathrm{Na}$ ich załogach spoczywał główny ciężar walki z siłami nieprzyjaciela na rzekach i lądzie. Jednostki te były uzbrojone w artylerię dużego kalibru oraz broń maszynową i posiadały silne opancerzenie. Kolejną kategorię stanowiły statki pancerne. Służyły one do przeprowadzania operacji na wodach płytkich i prowadzenia walki z oddziałami lądowymi wroga. Jednostki te mogły wykonywać akcje wywiadowcze oraz zabezpieczać transporty na rzekach, choć były zazwyczaj słabo opancerzone. Uzbrojenie statków pancernych stanowiła artyleria średniego kalibru. Z kolei trałowce były typem jednostek specjalistycznych. Ich zadaniem było stawianie i wyławianie min, a także likwidowanie innych przeszkód na rzekach. Posiadały one stosunkowo niewielkie wymiary i były wyposażone w sprzęt specjalistyczny, niezbędny do wykonywania zadań, zaś ich uzbrojenie składało się z broni ręcznej i maszynowej oraz min. Do kategorii mniejszych jednostek pływających należały też uzbrojone motorówki i ślizgacze (hydroglisery). Podstawowe ich zadania sprowadzały się do wykonywania rozpoznania, ochrony większych jednostek, konwojowania, a także wypadów i pełnienia funkcji łącznikowych. Ich zasadniczym atutem była stosunkowo znaczna prędkość, zaś minusem słabe opancerzenie. Uzbrojenie ich składało się 
z broni ręcznej i maszynowej. Jednak dzięki małemu zanurzeniu dysponowały największymi możliwościami pływania po płytkich akwenach śródlądowych. Pomocnicze jednostki pływające flotylli rzecznej stanowiły odrębną kategorię, do której zaliczano: statki sztabowe, sanitarne, holowniki, statki obrony przeciwlotniczej, warsztaty pływające, barki służące do transportowania żywności, paliwa, amunicji i żołnierzy. Wszystkie wymienione typy jednostek pływających wykorzystywano we Flotylli Rzecznej MW w Pińsku. Ponadto na wypadek działań wojennych przewidywano znaczną rozbudowę posiadanych jednostek rzecznych, głównie w drodze rekwizycji statków, barek i motorówek od osób prywatnych i instytucji cywilnych, z przeznaczeniem ich zasadniczo do zadań transportowych, a po odpowiednim uzbrojeniu również do działań bojowych ${ }^{35}$. W odniesieniu do wykorzystania jednostek pływających na Polesiu (pod koniec lat dwudziestych $\mathrm{XX}$ w.) oceniano, że największą rolę będą odgrywać monitory, jako siła główna, oraz uzbrojone motorówki, spełniające funkcje pomocnicze (wywiad i łączność).

Jak już wspomniano, na ograniczenia użycia jednostek pływających Flotylli Pińskiej, rzutowały głównie warunki nawigacyjne, występujące na rzekach Polesia. Na początku lat trzydziestych, największe jednostki pływające znajdujące się we flotylli miały zanurzenie (od 0,90 do 0,35 m) uniemożliwiające im w praktyce przepłynięcie Kanału Królewskiego, a tym samym przedostanie się ich drogą wodną na inne rzeki było niemożliwe. Zanurzenie rzecznych jednostek pływających zaprezentowano w poniższej tabeli ${ }^{36}$.

Tabela 1

Maksymalne zanurzenie jednostek pływających Flotylli Pińskiej w 1931 r.

\begin{tabular}{|l|c|}
\hline Typ jednostki pływającej & $\begin{array}{c}\text { Maksymalne } \\
\text { zanurzenie (w m) }\end{array}$ \\
\hline Monitory typu „Warszawa” & 0,90 \\
\hline Statki parowe & 0,85 \\
\hline Kutry ciężkie (ze śrubą) & 0,75 \\
\hline
\end{tabular}

${ }^{35}$ CAW-WBH, Akta KMW, t. 27, Plan stworzenia flotylli rzecznych w latach 1920-1929, k. 3-6. Vide: J. ВоReYкo, Flotylle Rzeczne, „Morze” 1926, nr 1, s. 10; Marynarka Wojenna, oprac. zbiorowe red. E. Kosiarz, J. Krasnowiecki, T. Mandat, E. Szpitun, Warszawa 1961, s. 129-130. Autorzy tego opracowania w kategorii okrętów rzecznych wymieniają: monitory, okręty artyleryjskie (kanonierki i kutry opancerzone) oraz trałowce rzeczne.

${ }^{36}$ CAW-WBH, Akta GISZ, t. 1929, Pismo oficera flagowego Flotylli Pińskiej do dowódcy Okręgu Korpusu nr IX z 21 V 1931 r., k. 1-2. 
Tabela 1 (cd.)

\begin{tabular}{|l|c|}
\hline Typ jednostki pływającej & $\begin{array}{c}\text { Maksymalne } \\
\text { zanurzenie }(\mathbf{w} \mathbf{~ m})\end{array}$ \\
\hline Kutry lekkie (ze śrubą) & 0,65 \\
\hline Monitory typu „Kraków” & 0,45 \\
\hline Trałowce & 0,35 \\
\hline
\end{tabular}

Źró d to: CAW-WBH, Akta GISZ, t. 1926, Pismo oficera flagowego flotylli do dowódcy Okręgu Korpusu nr IX z 21 V 1931 r., s. 1-2.

Z tabeli tej wynika, iż spośród sześciu typów jednostek pływających we Flotylli Pińskiej, największe problemy eksploatacyjne na wodach śródlądowych Polesia sprawiały monitory typu „Warszawa” (zwane gdańskimi), gdyż posiadały one największe zanurzenie wynoszące $0,90 \mathrm{~m}$. Dlatego też tym okrętom, które w przyszłych działaniach bojowych miały odegrać główną rolę, poświęcano we flotylli dużo czasu, podkreślając potrzebę zmniejszenia ich zanurzenia. Niesprzyjające warunki nawigacyjne na rzekach Polesia oraz okresowo niskie stany wody powodowały, że zaczęto poszukiwać rozwiązań, które pozwoliłyby na pływanie największych jednostek flotylli (o największym zanurzeniu) o każdej porze roku. Proponowane rozwiązania i prowadzone prace badawcze zmierzały w dwóch kierunkach: zmniejszenia zanurzenia i spiętrzenia wody na określonym odcinku rzeki ${ }^{37}$.

Ponieważ zanurzenie tych monitorów przy pełnym wyposażeniu wynosiło minimum $0,80 \mathrm{~m}$, przepłynięcie przez płytsze miejsca wymagało opróżniania komór amunicyjnych oraz zbiorników paliwa. Powyższe trudności próbowano rozwiązać w różny sposób, m.in. w 1933 r. powstał plan przecięcia monitorów wzdłuż, a następnie ich poszerzenia o $2 \mathrm{~m}$. Ostatecznie jednak zrezygnowano z tego rozwiązania. Kolejne doświadczenia przeprowadzono w 1935 r., kiedy to monitor "Warszawa” (kotwiczący na stojącej wodzie w porcie oraz na jeziorze koło m. Nyrcza) wyposażono w 6 pływaków, napełnionych wodą (przymocowane po $3 \mathrm{z}$ każdej burty). $\mathrm{Z}$ chwilą wypompowania wody pływaki spowodowały podniesienie burt o $0,16 \mathrm{~m}$ (zanurzenie rufy zmniejszyło się z 0,80 do 0,64 m). Prace doświadczalne z pływakami na monitorze „Warszawa” kontynuowano również w czerwcu 1936 r., gdy poziom wody na rzekach był wyjątkowo niski, a mielizny utrudniały pływanie jednostek o większym zanurzeniu, co opóźniało przemieszczanie się flotylli i utrudniało ćwiczenia. Jedynym rozwiązaniem w tej sytuacji

${ }^{37}$ CAW-WBH, Akta KMW, t. 576, Pismo dowódcy Flotylli Pińskiej do szefa KMW w sprawie pływaków i zagrody do spiętrzania wody z 12 III 1936 r., k. 1-2 
było zmniejszenie zapasu paliwa (o połowę) i całkowite rozbrojenie jednostki (co w warunkach bojowych nie mogło mieć miejsca). Zastosowanie pływaków do monitora „Warszawa” przy niskim stanie wody i zmniejszenie częściowo zapasu paliwa ograniczało zanurzenie jednostki nawet do około $0,60 \mathrm{~m}$, co umożliwiało jej przepłynięcie mielizn, na których osiadały inne jednostki. W związku z pozytywnymi wynikami tych prób, dowódca flotylli zwrócił się z prośbą do szefa KMW o wyrażenie zgody na budowę kolejnych pływaków (po wprowadzeniu pewnych udoskonaleń), dla pozostałych monitorów. W latach 1936-1938 wybudowano cztery komplety trójczłonowych pływaków przyczepianych do burt monitorów, dzięki którym ich zanurzenie zmniejszyło się do 0,60-0,64 m, co pozwalało im łatwiej przemieszczać się przy niskim stanie wody, jednak ich prędkość pływania zmniejszyła się z 13,5 do 10,5 km/godz. ${ }^{38}$

Kolejne doświadczenie - także z połowy lat trzydziestych - dotyczyło zbadania przydatności zagrody służącej do spiętrzania wody na rzece. Zrealizowano ją na rzece Horyń, powyżej m. Dawidgródek (w pobliżu m. Uholec). Testowana zapora składała się z dwóch części (przęseł) - każde o długości $20 \mathrm{~m}$. Po rozstawieniu zajmowała ona około $1 / 3$ szerokości koryta rzeki. Zaporę ustawiono w ciągu pół godziny, skutkiem czego woda nad mielizną podniosła się o około $2 \mathrm{~cm}$. W oparciu o uzyskane wyniki uznano, iż długość zastosowanej zapory do spiętrzania wody była zbyt mała, ponieważ zaraz po spiętrzeniu wody spływała ona na boki. Dlatego też stwierdzono potrzebę dodania do niej jeszcze jednego członu (elementu) o długości $20 \mathrm{~m}$. Oceniano, że zagroda składająca się z trzech przęseł o długości $60 \mathrm{~m}$ lub dłuższa mogłaby w znacznie większym stopniu podnieść poziom wody w płytkich miejscach, co umożliwiłoby przepłynięcie nad mieliznami jednostek Flotylli Pińskiej".

\section{Zakończenie}

Podsumowując dotychczasowe ustalenia, należy stwierdzić, że flotylle rzeczne II RP były zmuszone do prowadzenia działań na niewygodnym i niedostatecznie przygotowanym akwenie. Charakteryzował się on niekorzystnym układem granicy państwowej, a także trudnymi warunkami wodnymi i atmosferycznymi. W tym czasie w Europie Środkowej rzeki zimą zamarzały na 2-3 miesiące, a susze wywołane upałami letnimi skutkowały obniżeniem poziomu wód przeciętnie na 2-3 miesiące. Wpływało to na ograniczenie żeglugi, przy niesprzyjających warunkach wodnych, do 4-6 miesięcy w skali roku ${ }^{40}$.

${ }^{38}$ CAW-WBH, Akta KMW, t. 576, Pismo dowódcy Flotylli Pińskiej do szefa KMW w sprawie pływaków do monitorów z 5 VII 1936 r., k. 1-2.

${ }^{39}$ Ibidem.

${ }^{40}$ J. Dyskant, op. cit., s. 72. 
Polesie przysparzało szeregu trudności dla operujących tu wojsk, które wynikały z ograniczonych możliwości wykorzystania broni pancernej, artylerii i niedoskonałego jeszcze lotnictwa. Do zapewnienia panowania na tym obszarze wojsko musiało posiadać niezbędne środki przeprawowe i transportowe oraz być wspierane przez ruchome środki ogniowe. Istniejący na Polesiu układ sieci wodnej, przy znikomej sieci drogowej i kolejowej, rzutował na konieczność wykorzystania jednostek pływających flotylli w charakterze środków uniwersalnych - zarówno ogniowych, transportowych, jak i przeprawowych. Dlatego też flotylla ta posiadała teoretycznie duże znacznie, szczególnie $\mathrm{w}$ warunkach prowadzenia wojny ze Związkiem Radzieckim.

Prypeć, ze względu na swój dofrontowy bieg, umożliwiała i wręcz narzucała prowadzenie działań ofensywnych, do momentu osiągnięcia przez flotyllę linii Dniepru, gdzie jej jednostki pływające mogły realizować wypady w górę i dół tej rzeki. Za linią Dniepru Flotylla Pińska nie miała możliwości prowadzenia działań zaczepnych. Chociaż Prypeć była żeglowna na odcinku $555 \mathrm{~km}$, to jednak warunki hydrograficzne tej rzeki, związane z porami roku, często nie pozwalały na jej operacyjne wykorzystanie. Odcinkiem newralgicznym był środkowy bieg tej rzeki, który mógł być właściwie wykorzystany do prowadzenia działań bojowych tylko w okresie sprzyjających warunków wodnych.

W przypadku wojny ze Związkiem Radzieckim, przy niekorzystnym wyniku działań zaczepnych, rubież Prypeci była trudna do obrony, gdyż zasadniczo nie stanowiła poważnej przeszkody wodnej. Linie obronne można było zbudować, wykorzystując do tego celu południkowo płynące dopływy, które jednak nie zawsze były żeglowne dla okrętów Flotylli Pińskiej. Jednocześnie kręte koryta rzek utrudniały prowadzenie działań zespołom okrętów.

W ewentualnych działaniach bojowych szczególną rolę odgrywała rzeka Pina, Kanał Królewski i rzeka Muchawiec, które stanowiły arterię łączącą dorzecze Prypeci i Wisły. Była to jedyna droga odwrotu jednostek polskiej flotylli, stąd wymagała utrzymywania jej w stałej gotowości technicznej i eksploatacyjnej oraz zabezpieczenia na wypadek zagrożenia ze strony lotnictwa przeciwnika czy grup dywersyjnych. Ograniczone znaczenie w operacjach frontu polskiego mogła też mieć arteria wodna Jasiołda-Kanał Ogińskiego-Szczara, która łączyła dorzecze Prypeci i Niemna - również mogła być wykorzystana do budowy rubieży obronnej. Natomiast wykorzystanie w tym charakterze drogi ewakuacyjnej dla okrętów polskiej Flotylli Pińskiej w praktyce było mało istotne, ze względu na zbyt dużą długość tego przejścia przez Niemen do Wisły.

W obliczu wojny z Niemcami Flotylla Pińska była w stanie przerzucić większość okrętów Kanałem Królewskim do działań na dolnej Wiśle. W takiej sytuacji Polesie stawało się dla flotylli głębokim zapleczem, które jednak było narażone na działalność lotnictwa wroga i dywersantów. Jednocześnie, załamanie się polskiej 
obrony na dolnej Wiśle i Bugu decydowało o praktycznym wyłączeniu z działań bojowych Flotylli Pińskiej. Również wykorzystanie zaplecza Flotylli Pińskiej w postaci Portu Wojennego MW i Warsztatów MW w Pińsku, w przypadku wojny ze Związkiem Radzieckim było problematyczne ze względu na bliskość frontu. Tylko w przypadku wojny z Niemcami zaplecze to mogło funkcjonować i realizować zadania dla potrzeb flotylli, gdyż było ono zagrożone jedynie atakami lotniczymi ${ }^{41}$.

Należy stwierdzić, że Flotylla Rzeczna MW w Pińsku, podobnie jak Flotylla Wiślana, w swoich działaniach była uzależniona od panujących na Polesiu warunków hydrometeorologicznych oraz właściwej regulacji i utrzymania środkowego biegu Prypeci, systemu Kanału Królewskiego oraz środkowego i dolnego biegu Bugu. Jednak trudności ekonomiczne odrodzonej Polski nie pozwoliły na realizację tych prac w całości. Natomiast w przypadku wojny z Niemcami i usytuowaniu linii frontu na Wiśle - istniała możliwość przerzucenia tu większości jednostek Flotylli Pińskiej, celem ich wykorzystania do obrony przepraw i mostów na Wiśle, Bugu oraz Narwi. Pozostawienie jednostek pływających Flotylli Pińskiej w dorzeczu Prypeci zadecydowało z góry o jej dalszych losach i samozatopieniu.

Oceniając rolę, jaką obszar Polesia mógł odegrać w działaniach obronnych podczas przyszłej wojny ze wschodnim sąsiadem, należy zauważyć, iż strona polska w ogóle nie brała pod uwagę możliwości zaistnienia takiej sytuacji na froncie, w czasie której mogło nastąpić odcięcie i wyłączenie z działań bojowych stosunkowo niewielkich sił skoncentrowanych na tym terenie. Dopiero operacje wojskowe przeprowadzone podczas II wojny światowej dowiodły, że takie działania na polu walki są możliwe, a brak przewidywania takich rozwiązań przyczynił się do porażek znacznie większych zgrupowań wojska.

Na zakończenie warto przytoczyć ocenę możliwości działania Flotylli Pińskiej na Polesiu sporządzoną przez długoletniego dowódcę tej jednostki - kmdr. W. Zajączkowskiego:

Począwszy od roku 1937 poziom wody na Prypeci stawał się coraz niższy, a nawigacja coraz trudniejsza. O ile w 1935 roku uważane było, że jednostki o zanurzeniu $0,75 \mathrm{~m}$ są $\mathrm{w}$ stanie przy każdej porze roku swobodnie pływać po Prypeci, o tyle w 1939 r. nawet małe kanonierki o zanurzeniu $0,45 \mathrm{~m}$ nie były w stanie przejść wielu mielizn bez długotrwałego i żmudnego przeciągania ich. Pomimo, że dla monitorów typu „Torun” zostały skonstruowane specjalne pływaki wynurzające je o 0,18 m, monitory te w sierpniu i wrześniu 1939 r. były prawie unieruchomione, a przesuwanie ich rzeką nosiło charakter żmudnego przepychania po kilka lub kilkanaście godzin z mielizny na mieliznę. Statki dywizjonowe i pomocnicze, jak „Generał Szeptycki”, „Hetman Chodkiewicz”, „Generał Sikorski” i „Generał Sosnkowski” były zupełnie unieruchomione. Pierwszy z nich nie

\footnotetext{
${ }^{41}$ Ibidem, s. 74.
} 
mógł wyjść z Pińska, dalsze 3 stały w rejonie Mostów Wolańskich, mając zaledwie $4 \mathrm{~km}$ przestrzeni, po której mogły się poruszać. Z tychże względów monitory nie mogły załadować więcej niż po kilkadziesiąt pocisków i tylko nieznaczną ilość paliwa. Przechodzenie do granicy [z ZSRR - I.B.] i zajmowanie stanowisk trwało 3 dni, nie zważając, że Flotylla szła „z prądem”. Wciąż była nadzieja, że ze względu na zbliżającą się jesień, woda lada chwila podniesie się. W rzeczywistości woda opadała wciąż dalej $[\ldots]^{42}$.

Ireneusz Bieniecki

\title{
POSSIBILITIES OF COMBATING ACTIVITIES ON THE INLAND WATER OF THE REPUBLIC OF POLAND ON THE EXAMPLE OF THE RIVER FLEET OF THE NAVY IN PIŃSK
}

\begin{abstract}
Summary: The article presents the restrictions related to the conduct of combat operations by the vessels of the Navy River Fleet in Pinsk. It provides discussion of issues such as war doctrine of the Second Polish Republic and river fleets, geographical characteristics of Polesie, possibilities of conducting activities by the Pinsk Fleet in the assessment of commanders and superiors, as well as technical parameters of vessels and the resulting restrictions.
\end{abstract}

Keywords: the River Fleet of the Navy in Pińsk (1919-1939), possibilities of conducting activities Fleet in Polesie.

${ }^{42}$ Muzeum Marynarki Wojennej w Gdyni, sygn. nr 566, Relacja W. Zajączkowskiego pt. Historia Flotylli rzecznej MW w kampanii wrześniowej 1939 r., k. 8-9. 